\title{
PENERAPAN MODEL PEMBELAJARAN PBL TERINTEGRASI PENDIDIKAN KARAKTER UNTUK MENINGKATKAN HASIL BELAJAR KOGNITIF MAHASISWA
}

\author{
Muhammad Irwansyah ${ }^{1}$, Ferawati ${ }^{2}$ dan Erni Suryani ${ }^{3}$ \\ 1,2Program Studi Pendidikan Biologi, STKIP Bima. Jalan Piere Tendean Kel. Mande \\ Tel. Fax (0374) 42801, Bima84191, Indonesia. \\ Email: irwansyahmuh44@gmail.com
}

\begin{abstract}
Abstrak: Penelitian ini adalah penelitian tindakan kelas (PTK). Subjek penelitian adalah mahasiswa program studi pendidikan biologi STKIP Bima tahun ajaran 2017/2018. Adapun tujuan penelitian adalah untuk meningkatkan hasil belajar kognitif mahasiswa program studi pendidikan biologi STKIP Bima dengan menggunakan model pembelajaran PBLterintegrasi pendidikan karakter. Instrumen yang digunakan yaitu tes hasil belajar kognitif. Teknik analisis data menggunakan gain score. Hasil penelitian menunjukkan bahwa pada siklus I diperoleh rerata sebesar $75 \%$ dan rerata siklus II sebesar $85 \%$, mengalami peningkatan sebesar $10 \%$ dengan Gain Score 0,5 tergolong sedang.
\end{abstract}

\section{Kata Kunci: PBL, Pendidikan Karakter, Kognitif}

\section{PENDAHULUAN}

Pada tahun 2045 nanti pemerintah Indonesia memiliki cita-cita menciptakan sumber daya manusia yang memiliki kemampuan untuk bertahan hidup diabad 21 atau yang disebut dengan generasi emas. Menurut Sani (2014) adapun beberapa keterampilan yang harus dimiliki oleh sumber daya manusia agar mampu bertahan hidup diabad 21 yaitu kreativitas dan inovasi, kemampuan berpikir kritis dan menyelesaikan masalah, komunikasi dan kolaborasi, keterampilan sosial dan budaya, serta penguasaan teknologi informasi.

Perguruan tinggi merupakan salah satu tempat untuk menghasilkan sumber daya manusia yang mampu bertahan hidup sesuai dengan perkembangan dan tuntutan zaman atau sumber daya manusia yang mampu bertahan hidup diabad 21.Sebab perguruan tinggi bertujuan untuk mengembangkan potensi mahasiswa agar menjadi manusia yang beriman dan bertaqwa kepada Tuhan Yang Maha Esa, berakhlak mulia, sehat, berilmu, terampil, kompeten dan berbudaya (UU No. 12 Tahun 2012).

Sekolah tinggi keguruan dan ilmu pendidikan (STKIP) Bima merupakan salah satu perguruan tinggi swasta yang ada di kotaBima propinsi Nusa Tenggara Barat. Demi merealisasikan amanah UU No. 12 tahun 2012 STKIP Bima memiliki visi menjadi sekolah tinggi pencetak pendidik dan tenaga kependidikan yang memiliki kompetensi profesional, berorientasi riset dan 
pengembangan ilmu pengetahuan, teknologi dan seni (IPTEKS) pada tahun 2020.

Berdasarkan hasil observasi awal pada mahasiswa program studi pendidikan biologi STKIP Bima, pola perkuliahan yang diterapkan sebagian masih didominasi oleh strategi pembelajaran yang sifatnya konvensional tanpa mengintegrasikan dengan penguatan pendidikan karakter. Hal tersebut menyebabkan sebagian mahasiswa belum memiliki kemampuan berpikir kritis, berpikir kreatif,pemecahan masalah sehingga hasil belajar kognitif mahasiswa rendah.

Oleh karena itu untuk merealisasikan visi STKIP Bima perlu adanya kegiatan pembelajaran inovatif yaitu proses pembelajaran yang mampu menghasilkan sumber daya manusia yang cerdas, berpikir kritis, berpikir kreatif,serta memiliki kemampuan menyelesaikan masalah tanpa melanggar aturan kampus. Salah satu model pembelajaran yang menawarkan hal tersebut adalah model pembelajaran problem based learning (PBL) terintegrasi pendidikan karakter. Berdasarkan hasil penelitian syafi' $i$ (2011), danDwi (2013) bahwa penerapan model pembelajaran problem based learning (PBL) dapat meningkatkan kemampuan berpikir kreatif, penguasaan konsep, dan kemampuan pemecahan masalah peserta didik.

Berdasarkan uraian diatas penulis termotivasi untuk melakukan penelitian dengan judul penerapan model pembelajaran problem based learning (PBL) terintegrasi pendidikan karakter untuk meningkatkan hasil belajar kognitif mahasiswa program studi pendidikan biologi STKIP Bima.

\section{METODE}

Penelitian ini adalah penelitian tindakan kelas (PTK). Karakteristik yang khas dari penelitian tindakan kelas yakni tindakantindakan (aksi) yang berulang-ulang untuk memperbaiki proses belajar-mengajar di kelas.Langkah-langkah tindakan yang ditempuh merupakan kerja yang berulang (siklus) sehingga diperoleh pembelajaran yang dapat meningkatkan hasil belajar kognitif mahasiswa program studi pendidikan biologi STKIP Bima tahun ajaran 2017/2018.

Penelitian ini dilaksanakan pada bulan Mei sampai dengan Juli 2018.Subjek penelitian yaitu mahasiswa program studi pendidikan biologi STKIP Bima semester VI kelas D yang berjumlah 24orang.Teknik pengumpulan data aspek hasil belajar kognitif menggunakan tes hasil belajar kognitif yang dilakukan ditiap siklusnya.SelanjutnyaHasil tindakan setiap siklus dianalisis menggunakan rumus Gain Score ternormalisasi.Tingkat perolehan Gain Score ternormalisasi dikategorikan ke dalam tiga kategori, yaitu: $g$ - tinggi jika $(<\mathrm{g}>)>0,7 ; \mathrm{g}-$ sedang jika $0,7 \geq$ 
$(<\mathrm{g}>) \geq 0,3$; dan $\mathrm{g}-$ rendah jika $(<\mathrm{g}>)<$ 0,3.(Hake, 1998).

\section{HASIL DAN PEMBAHASAN}

Hasil penelitian berupa penilaian hasil belajar kognitif mahasiswa melalui penerapan model pembelajaran problem based learning (PBL)terintegrasi pendidikan karakter menggunakan Gain
Score ternormalisasi siklus I tertera pada Tabel 1 menunjukkan bahwa hasil belajar kognitif mahasiswa pada siklus I rerata sebesar $75 \%$ dan rerata siklus II sebesar $85 \%$, mengalami peningkatan sebesar $10 \%$ dengan Gain Score 0,5 tergolong sedang seperti tertera pada tabel 1 berikut ini:

Tabel 1: Hasil Penilaian Postes Siklus I dan Siklus II Hasil Belajar Kognitif Mahasiswa Program Studi Pendidikan Biologi STKIP Bima

\begin{tabular}{cccc}
\hline Rata-Rata Tes Kognitif & \multicolumn{3}{c}{ Rata-Rata Tes Kognitif } \\
\hline Siklus I & Siklus II & Peningkatan & Gain Score \\
\hline 75 & 85 & 10 & 0,5 \\
\hline
\end{tabular}

Berdasarkan hasil penelitian bahwa ratarata nilai siklus I dan siklus II mahasiswa semester VI kelas D menunjukkan adanyapeningkatan hasil belajar kognitif mahasiswa melalui model pembelajaran problem based learning (PBL)terintegrasi pendidikan karakter. Dimana data perolehan hasil belajar kognitif mahasiswa pada siklus I sebesar $75 \%$, sedangkan pada siklus II sebesar $85 \%$ mengalami peningkatan sebesar $10 \%$ dengan gain score 0,5 kategori sedang. Kondisi tersebut menunjukkan bahwa penerapan model pembelajaran problem based learning (PBL)terintegrasi pendidikan karakter efektif dalam meningkatkan hasil belajar kognitif mahasiswa program studi pendidikan Biologi STKIP Bima.
Alasan mendasar diterapkannya model pembelajaran problem based learning (PBL)terintegrasi pendidikan karakter pada mahasiswa program studi pendidikan biologi STKIP Bimadisebabkan karna dalam proses perkuliahan selama ini mahasiswa lebih banyak ditempatkan sebagai pendengar setia saatdosen menyampaikan materi perkuliahan. Dan tidak ditemukan penguatan pendidikan karakter saat pembelajaran.

Sementara itu penerapan model pembelajaran problem based learning (PBL) terintegrasi pendidikan karakter mahasiswa terlibat langsung dalam diskusi, tanya jawab, kerja sama dan mahasiswa dibimbing oleh dosen agar mencarikan solusi terhadap permasalahan kontekstual yang terjadi 
dimasyarakat. Melalui kegiatan diskusi, tanya jawab dan kerjasama dapat melatih mahasiswa berpikir kritis, berpikir kreatif dan menyelesaikan masalah sehingga pada saat pemberian postes terjadi peningkatan kemampuan kognitif mahasiswa.

Temuan yang mendukung penelitian ini adalah hasil penelitian Darmawati \& Mahadi (2014) tentang peningkatan kemampuan soft skills mahasiswa biologi FKIP universitas Riau pada matakuliah genetika dan evolusi melalui penerapan model pembelajaran problem based learning (PBL). Temuan lain sebagai pendukung penelitian ini adalah hasil penelitian Sari (2012) tentang penerapan model problem based learning (PBL) dapat meningkatkan kemampuan berpikir kritis peserta didik pada pembelajaran IPA.

Oleh karena itu hasil penelitian ini menunjukkan pembelajaran model problem based learning(PBL)terintegrasi pendidikan karaktersangat efektif terhadap peningkatan kemampuan berpikir kritis siswa. Peningkatan masing-masing indikator berfipir kritis tersebut antara lain indikator definisi dan klarifikasi masalah dari cukup menjadi baik, kemudian indikator menilai informasi berdasarkan masalah kriteria penilaiannyameningkat dari cukup menjadi baik, dan indikator merancang solusi berdasarkan masalah kriterianya penilaiannya meningkat dari cukup menjadi baik.
Model pembelajaran problem based learning (PBL)terintegrasi pendidikan karakter melibatkan rangkaian aktivitas pembelajaran yang menekankan kepada proses penyelesaian masalah yang dihadapi secara ilmiah yang dimana mahasiswa tidak hanya sekedar menghafal materi perkuliahan akan tetapi melalui model pembelajaran problem based learning (PBL)terintegrasi pendidikan karakterberbagai tahapan yang mampu meningkatkan pengetahuan mahasiswa. Melalui kegiatan pemecahan masalah yang dilakukan dengan pendekatan berpikir secara ilmiah, mahasiswa mampu menyelesaikan masalah yang didasarkan pada data dan fakta yang jelas (Sanjaya, 2006).

Pembelajaran menggunakan model pembelajaranproblem based learning (PBL)terintegrasi pendidikan karakter meningkatkan kemampuan berpikir kritis dan berpikir kreatif mahasiswa, hal ini ditandai dengan antusiasme mahasiswa dalam proses perkuliahan, yakni mahasiswa mengembangkan kemampuan dalam mengajukan pertanyaan, menjawab pertanyaan, serta menganalisis masalah sesuai dengan konteks kehidupan nyata. Pada tahapan mempresentasikan hasil diskusi kelompok kepada kelompok lain. Proses pembelajaran terlihat lebih aktif, karena pada tahap diskusi kelompok mahasiswa lebih berani untuk mengemukakan pendapat serta 
mempertahankan pendapatnya. Pada tahap terakhir dalam pembelajaran menggunakan model pembelajaranproblem based learning (PBL)terintegrasi pendidikan karakter yakni tahap evaluasi, mahasiswadiharapkan untukmembuat kesimpulan akhir dari proses pembelajaran yang telah dilakukan. Diharapkan setelah membuat kesimpulan mahasiswa memiliki pemahaman konsepmengenai permasalahan yang telah dibahas

\section{KESIMPULAN}

Berdasarkan hasil analisis data dan temuan penelitian serta pembahasan, dapat disimpulkan bahwa melalui penerapan model pembelajaranproblem based learning (PBL) terintegrasi pendidikan karakter dapat meningkatkan hasil belajar kognitif mahasiswa program studi pendidikan biologi STKIP Bima.

\section{Ucapan Terimakasih}

Penulis menyampaikan ucapan terima kasih kepada Pimpinan STKIP Bima yang telah mendanai kegiatan penelitian ini sehingga penelitian ini dapat terlaksana dengan sukses.

\section{DAFTAR PUSTAKA}

Darmawati \& Mahadi, I. (2014). Peningkatan Kemampuan Soft Skill Mahasiswa Biologi FKIP Universitas Riau Pada Matakuliah Genetika dan Evolusi
Mellaui Penerapan Model Pembelajaran Problem Based Learning (PBL) Jurnal Biogenesis, Vol. 10. (2). 16-17.

Dwiet.all. (2013). Pengaruh Strategi Problem Based Learning Berbasis ICT Terhadap Pemahaman Konsep dan Kemampuan Pemecahan Masalah Fisika.Jurnal Pendidikan Fisika Indonesia. 2013. (9). 16.

Hake, R.R. (1998). Interactive-Engagement vs Traditional Methods: a six-thousandstudent Survey of Mechanics Test Data for Introductory Physics Courses.American Journal of Physics. $66(1)$.

Sanjaya, W. (2006). Strategi Pembelajaran Berorientasi Standar Proses Pendidikan.Jakarta: Kencana.

Sari, D. D. (2012). Penerapan Model Problem Based Learning (PBL) Untuk Meningkatkan Kemampuan Berfikir Kritis Peserta Didik Pada Pembelajaran IPA Kelas VIII SMP Negeri 5 Sleman. Skripsi. Universitas Negeri Yogyakarta. Tidak Diterbitkan.

Sani, A.R. (2014). Pembelajaran Saintifik untuk Implementasi Kurikulum 2013.Jakarta: Bumi Aksara.

Syafi'i et.all. (2011). Kemampuan Berpikir Kreatif dan Penguasaan Konsep Siswa melalui Problem Based Learning (PBL) dalam Pembelajaran Biologi Kelas XI IPA SMAN 2 Pekanbaru Tahun Ajaran 2010/2011. Jurnal Biogenesis. Vol. 8. (1). 1.

Undang-Undang Pendidikan Tinggi No.12 Tahun 2012. Diakses pada tanggal 24 Maret 2017. 